http://dx.doi.org/10.1590/0370-44672017710173

\author{
Denise de Fátima Santos da Silva \\ Mestre \\ Universidade Federal de Ouro Preto - UFOP \\ Escola de Minas \\ Núcleo de Geotecnia \\ Ouro Preto - Minas Gerais - Brasil \\ denisefssilva61@gmail.com
}

\section{Allan Erlikhman Medeiros Santos \\ http://orcid.org/0000-0003-1241-8423 \\ Doutorando \\ Universidade Federal de Ouro Preto - UFOP \\ Escola de Minas \\ Departamento de Engenharia de Minas \\ Professor do Instituto Federal Goiano - Catalão - Goiás \\ Ouro Preto - Minas Gerais - Brasil \\ allanboni@hotmail.com}

\section{Bruno Trindade Ferreira}

Mestrando

Universidade Federal de Ouro Preto - UFOP

Escola de Minas

Departamento de Engenharia de Minas

Ouro Preto - Minas Gerais - Brasil

btrindade.ferreira@gmail.com

\section{Tiago Martins Pereira}

Professor-Adjunto

Universidade Federal de Ouro Preto - UFOP

Instituto de Ciências Exatas e Biológicas - ICEB

Departamento de Estatística

Ouro Preto - Minas Gerais - Brasil

tiago.martin@gmail.com

\section{Rosyelle Cristina Corteletti}

Professora Colaboradora

Universidade Federal de Ouro Preto - UFOP

Escola de Minas

Núcleo de Geotecnia

Ouro Preto - Minas Gerais - Brasil

rosyelleccorteletti@gmail.com

\section{Introduction}

Predicting the area and volume of rock mass in landslides is a matter of extreme complexity. Some cases allowed equating landslides in different parts of the world. The empirical relationships allow estimat-

\title{
Cluster analysis for slope geotechnical prioritization of intervention for the Estrada de Ferro Vitória-Minas
}

\begin{abstract}
This article proposes the geotechnical prioritization of intervention of slopes with landslide scars for the Estrada de Ferro Vitória-Minas by cluster analysis and also the proposition of a relationship between area and volume in landslide scars. Cluster definition helps the decision-making associated to containment measures, mapping and study of landslides for the Estrada de Ferro Vitória-Minas. The database is composed of the variables: slope's height, inclination, scar area and scar volume. The distance measure used was Gower's index, with Ward's methods to build the clusters. Eight characteristic groups were identified. It was possible to identify stretches that need attention in relation to the propensity of landslides, such as Group 7, stretches 362+600, 093+xxxE and 419+000. Group 7 presented high values for the scarred area and volume, such as maximum area $9.75 \times 104 \mathrm{~m}^{2}$ and minimum area $7.49 \times 10^{4} \mathrm{~m}^{2}$, and maximum volume $9.20 \times 10^{5} \mathrm{~m}^{3}$ and minimum volume $4.08 \times 10^{5} \mathrm{~m}^{3}$. Group 7 presented high ranges for slope height and inclination. The set of results about Group 7 can be interpreted as stretches with a predisposition for landslides. In relation to intervention measures, Group 7 presents the sections with priority. The relationship between area and volume of landslide scars obtained by the research was compared with the relationships established in literature.
\end{abstract}

Keywords: geotechnical prioritization of intervention of railway slopes, Estrada de Ferro Vitória-Minas, cluster analysis, multivariate statistics applied to geotechnical database, landslide scars.

ing parameters of landslides as a function of characteristics that can be determined, such as slope inclination and height. The empirical relationships allow the assessment and delimitation of areas of risk, allowing conviviality with natural phenomena. In addition, they also allow the preparation of programs to prevent, alert, and implement containment construction (Polanco, 2010).

This study was developed taking as 
reference the railroad line of the Estrada de Ferro Vitória-Minas (EFVM), Vale S.A., which is inserted in the states of Minas Gerais and Espírito Santo. The railroad has $929 \mathrm{~km}$ of extension and the trajectory of the trunk line is $540 \mathrm{~km}$. The geology that covers the study area, includes dominant lithologic classes in the trunk line of the EFVM, such as granites, gneisses, gneisses with mafic intrusives, metasedimentary rocks with presence of granitic intrusions, shales and gneisses and unconsolidated sediments.

In 1997, the company Vale S.A.

\section{Materials and methods}

The database used in this article was compiled from the data of Gomes' work (2014) in conjunction with image analysis of the Google Earth Pro

software and field work in the studied stretches of the railway.

The variables collected on the slopes are slope's height (HT) and

\begin{tabular}{c|c|c|c} 
Name & Definition in database & Bands & Classification \\
\hline \multirow{3}{*}{ Slope's height } & \multirow{3}{*}{$\mathrm{HT}$} & $\mathrm{HT}<6$ meters & Low \\
\cline { 3 - 4 } & & 6 meters $<\mathrm{HT}<10$ meters & Average \\
\cline { 3 - 4 } & & $\mathrm{HT}>10$ meters & High \\
\hline
\end{tabular}

\begin{tabular}{c|c|c|c} 
Name & Definition in database & Bands & Classification \\
\hline \multirow{2}{*}{ Slope's inclination } & \multirow{2}{*}{$\mathrm{IT}$} & $\mathrm{IT}<60^{\circ}$ & Low \\
\cline { 3 - 4 } & & $\mathrm{IT}>60^{\circ}$ & High \\
\hline
\end{tabular}

The scar's area and scar volume variables are quantitative and were estimated in fieldwork in conjunction

with the use of Google Earth Pro software images and tools. Figure 1 shows the $493+600$ stretch with a slide

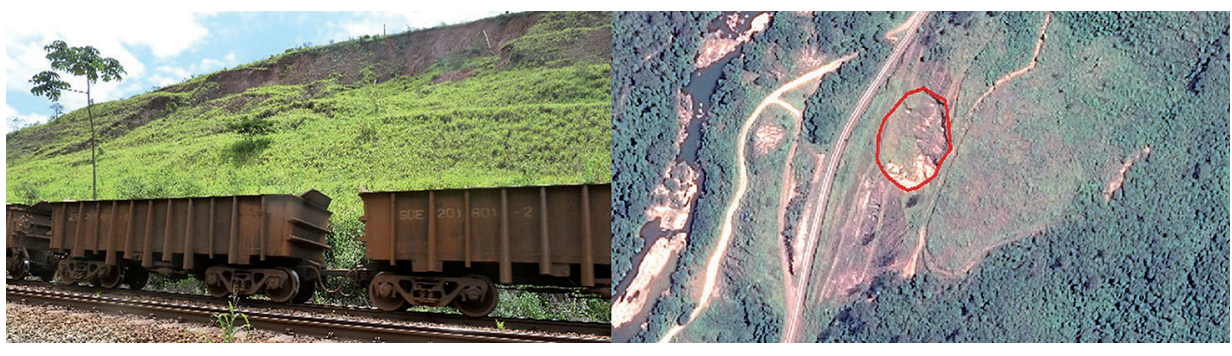

The processing of database and cluster analysis, along with the final script was performed in software $\mathrm{R}, \mathrm{R}$ Core Time (2016), version 1.0.136.

Ward's method presented better

The database is composed of quantitative and qualitative variables, mixed variables, and therefore

$G_{i k}$ - Gower's distance between the individuals $\mathrm{j}$ and $\mathrm{k}$ suitability for the database. According to Ward (1963) Ward's method is to use the individuals themselves to construct the overall measure of group heterogeneity (W), that is, the method assumes that

$$
W=\sum_{g} \sum_{i \in g}\left(X_{i g}-\bar{X}_{g}\right)^{t}\left(X_{i g}-\bar{X}_{g}\right)
$$

for the distance measurement of similarity, used was the Gower distance. Gower's distance was defined

$$
G_{j k}=\left(\sum_{i=1}^{n} W_{i j k} S_{i j k} / \sum_{i=1}^{n} W_{i j k}\right)
$$

$W_{i j k}$ - Variable weight i between the individuals $\mathrm{j}$ and $\mathrm{k}$ interpret the sectorization of the railroad and prioritization of intervention on slopes with landslides. The prioritization will be based on slope height, inclination, scar area and volume variables analyzed by cluster analysis. The cluster's definition helps the decision-making associated to containment measures, mapping and study of landslides for the Estrada de Ferro Vitória-Minas. In this context this work can contribute to studies about landslides in Brazil, through the proposition of empirical relationships for landslide control estimates.

inclination (IT). These variables are qualitative, classified by Gomes (2014) in bands presented in Tables 1 and 2 .

Table 1

Slope's height variable definition.

Table 2

Slope's inclination variable definition.

scar, field image and Google Earth Pro image.

Figure 1

Partial view of landslide's scar in stretch $493+600$ of EFVM (left). Image of the year 2016 from Google Earth Pro of stretch $493+600$ with polygon marking the scar (right).

each individual forms a group. W represents the sum of the squared Euclidean distances between each individual, $\mathrm{i}$, and the mean of their corresponding group, $\mathrm{g}$, see Equation 1.

by Gower (1971) and is presented in Equation 2.

$S_{i j k}$ - Partial similarity of variable i between the individuals $\mathrm{j}$ and $\mathrm{k}$ 


\section{Results and discussions}

In order to analyze the relationship between the variables to obtain the

Figure 2

Relation between

variables: scar's area and volume.

The correlation coefficient between the scar's area and volume variables

Equations 3 and 4 can be compared with the relationships proposed by Simonett (1967), Rice et al. (1969), Innes (1985), Guthrie and Evans (2004), Korup (2005), Imaizumi and Sidle

Table 3

Empirical relationships between volume and area of landslide scars.

In order to calculate the similarities between the slopes, the Gower's distance was used and to create the grouping, the Ward's method was parametric relationship, a regression was performed between the two variables: scar's area and volume. Figure 2 presents the result.

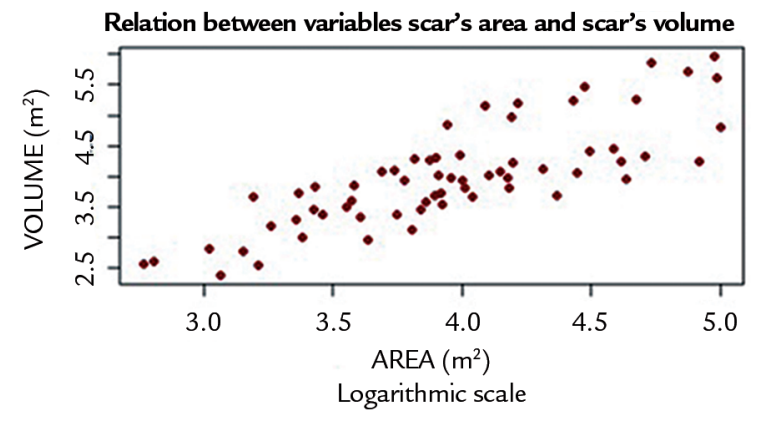

was 0.66. Equations 3 and 4 present the relationship between the two variables,

$$
\begin{gathered}
\log (V)=0.7338 \log (A)^{1.2249} \\
V=0.1416(A)^{1.2237}
\end{gathered}
$$

(2007), Guzzetti et al. (2008) and Imaizumi et al. (2008). The main differences between the relationships may be due to the local geology, the data collection period, and the number of slopes stud- which was obtained by means of the graph presented in Figure 2.

ied. Table 3 presents the relationships cited and the relationship found in this research, and it is possible to conclude that the relationship is in agreement with literature.

\begin{tabular}{c|c|c|c|c} 
Author & Relationship & Cases & Areas bands & Unit \\
\hline Present work & $\mathrm{V}=0.1416 \times \mathrm{A}^{1.2237}$ & 64 & $5.8 \times 10^{2}<\mathrm{A}<1.0 \times 10^{5}$ & $\mathrm{~m}^{2}$ \\
\hline Simonett $(1967)$ & $\mathrm{V}=0.2049 \times \mathrm{A}^{1.3680}$ & 207 & $2.5 \times 10^{1} \leq \mathrm{A} \leq 2.0 \times 10^{6}$ & $\mathrm{ft}^{2}$ \\
\hline Rice et al. (1969) & $\mathrm{V}=0.2340 \times \mathrm{A}^{1.1100}$ & 29 & $2.1 \times 10^{0} \leq \mathrm{A} \leq 2.0 \times 10^{2}$ & $\mathrm{~m}^{2}$ \\
\hline Innes (1985) & $\mathrm{V}=0.0329 \times \mathrm{A}^{1.3852}$ & 30 & $3.0 \times 10^{1} \leq \mathrm{A} \leq 5.0 \times 10^{2}$ & $\mathrm{~m}^{2}$ \\
\hline Guthrie and Evans (2004) & $\mathrm{V}=0.1549 \times \mathrm{A}^{1.0905}$ & 124 & $7.0 \times 10^{2}<\mathrm{A}<1.2 \times 10^{5}$ & $\mathrm{~m}^{2}$ \\
\hline Korup (2005) & $\mathrm{V}=0.0200 \times \mathrm{A}^{1.9500}$ & 23 & & $\mathrm{~A}>1.2 \times 10^{6}$ \\
\hline Imaizumi and Sidle (2007) & $\mathrm{V}=0.3900 \times \mathrm{A}^{1.3100}$ & 51 & $1.0 \times 10^{1}<\mathrm{A}<3.0 \times 10^{3}$ & $\mathrm{~m}^{2}$ \\
\hline Guzzetti et al. (2008) & $\mathrm{V}=0.0844 \times \mathrm{A}^{1.4324}$ & 539 & $1.0 \times 10^{1}<\mathrm{A}<1.0 \times 10^{9}$ & $\mathrm{~m}^{2}$ \\
\hline Imaizumi et al. (2008) & $\mathrm{V}=0.1900 \times \mathrm{A}^{1.1900}$ & 11 & $5.0 \times 10^{1}<\mathrm{A}<4.0 \times 10^{3}$ & $\mathrm{~m}^{2}$ \\
\hline
\end{tabular}

used. The cophenetic correlation in Ward's method was 0.68 , presenting an adequate value for the research. The choice of number groups was helped by the analysis of distance chart in groups and by the dendrogram analysis presented in Figure 3. 


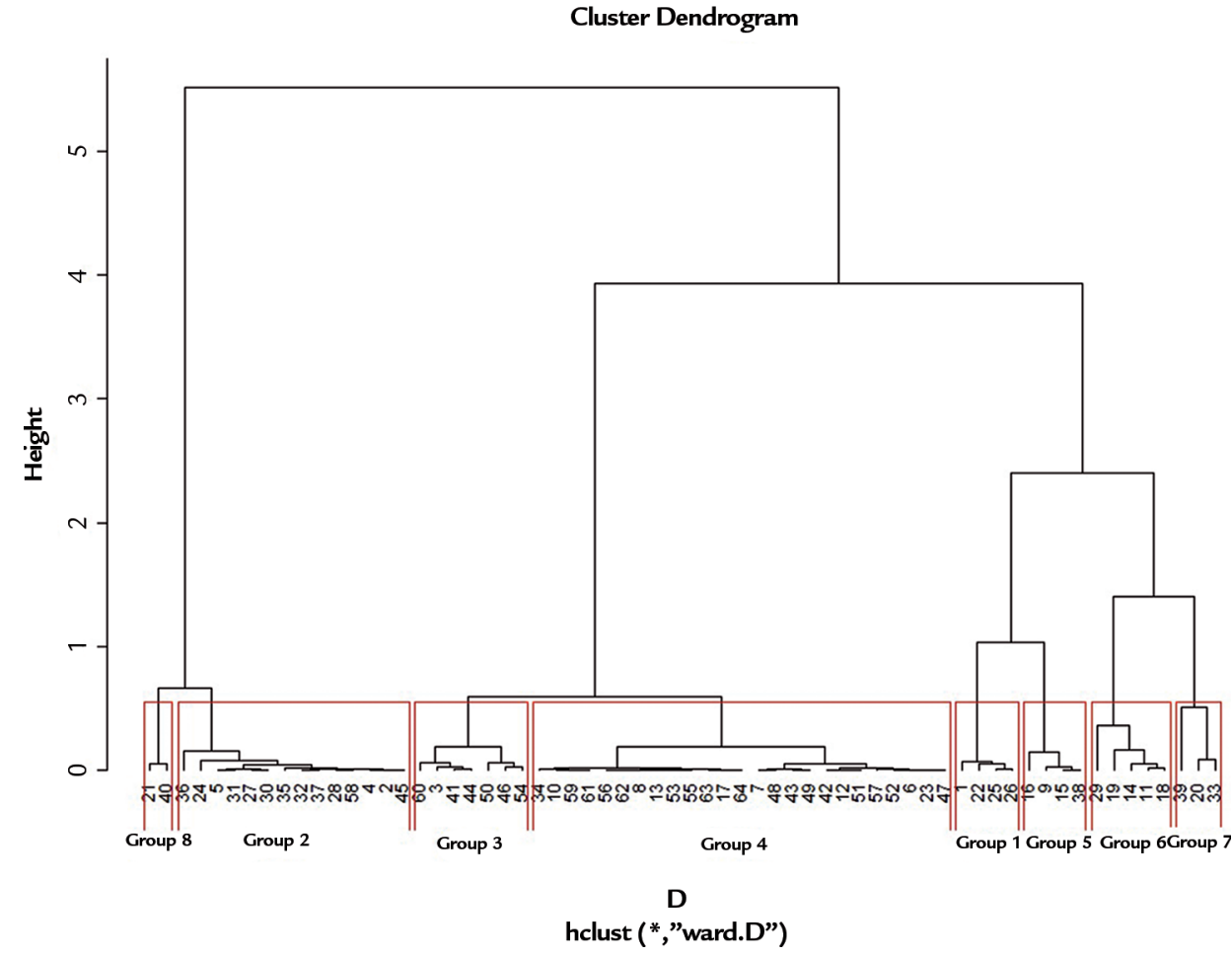

For analysis of the dendrogram, presented in Figure 4, with the characteristics of the slope's scars, eight groups were selected for the studied stretches of the EFVM.

For the results of the cluster analysis, in relation to the quantitative variables, scar's area and scar's volume, the cluster technique was able to separate the area and volume bands
Figure 3

Cluster dendrogram, Ward's method.

characterizing each group. Figures 4 and 5 show the boxplot of the variables with the bands comprising each group for the area and volume variables, respectively.

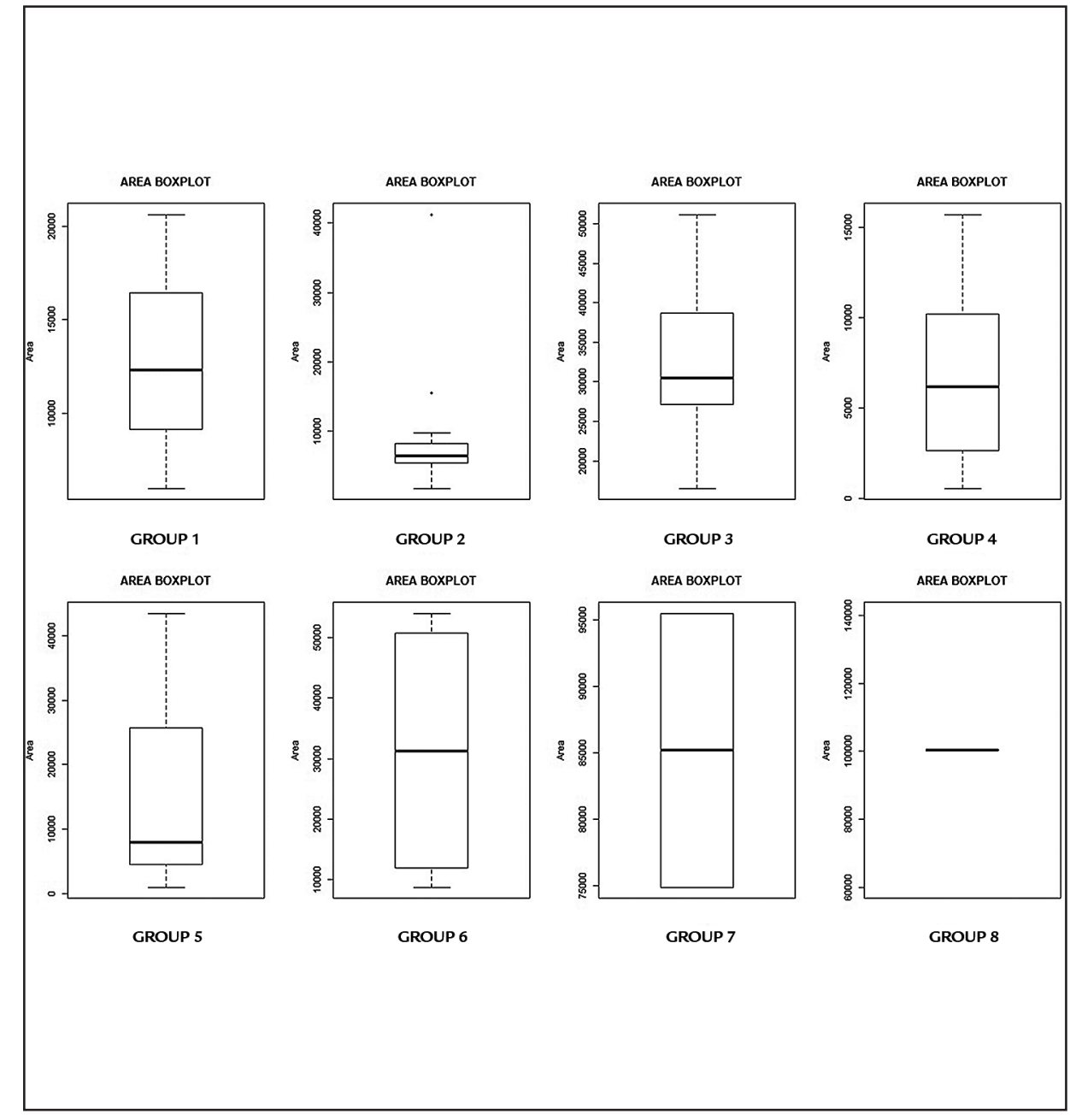

Figure 4

Area boxplot. 


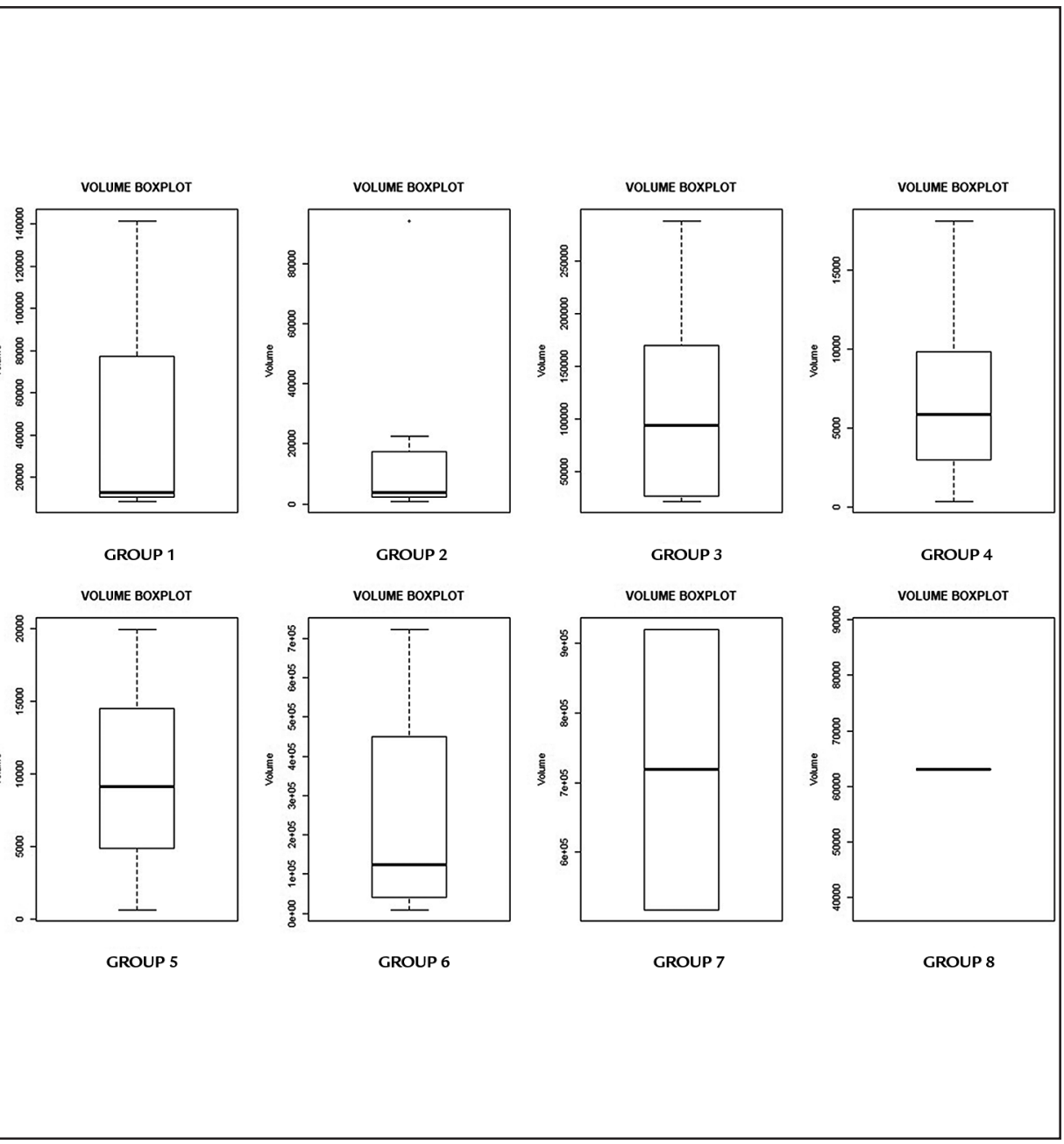

When analyzing only the quantitative variables, it was observed that this technique was able to identify ranges for the scar's area and volume. In the case of the scar's area variable, the bands in some cases overlap; however, it does not happen in the whole set values because each track presents unique values. For the volume, it is possible to observe that bands differ as to maximum values, not causing differences in the minimum values, except for Group 7.
Analyzing the final results of clustering in the whole database, qualitative and quantitative variables, it was possible to build Table 4, which presents the final characteristics of each group.

Table 4

Final characteristics of groups.

\begin{tabular}{c|c|c|c|c|c|c|c} 
Group & $\begin{array}{c}\text { Number } \\
\text { of slopes }\end{array}$ & $\begin{array}{c}\text { Slope's } \\
\text { height }\end{array}$ & $\begin{array}{c}\text { Slope's } \\
\text { inclination }\end{array}$ & $\begin{array}{c}\text { Maximum } \\
\text { area }\left(\mathrm{m}^{2}\right)\end{array}$ & $\begin{array}{c}\text { Minimum } \\
\text { área }\left(\mathrm{m}^{2}\right)\end{array}$ & $\begin{array}{c}\text { Maximum } \\
\text { volume }\left(\mathrm{m}^{3}\right)\end{array}$ & $\begin{array}{c}\text { Minimum } \\
\text { volume }\left(\mathrm{m}^{3}\right)\end{array}$ \\
\hline Group 1 & 4 & low & low & $2.06 \times 10^{04}$ & $1.62 \times 10^{03}$ & $1.42 \times 10^{05}$ & $3.40 \times 10^{02}$ \\
\hline Group 2 & 14 & high & low & $4.12 \times 10^{04}$ & $6.38 \times 10^{02}$ & $9.42 \times 10^{04}$ & $4.01 \times 10^{02}$ \\
\hline Group 3 & 7 & high & high & $5.11 \times 10^{04}$ & $1.65 \times 10^{04}$ & $2.89 \times 10^{05}$ & $1.17 \times 10^{04}$ \\
\hline Group 4 & 25 & high & high & $1.57 \times 10^{04}$ & $5.81 \times 10^{02}$ & $1.81 \times 10^{04}$ & $2.41 \times 10^{02}$ \\
\hline Group 5 & 4 & low & high & $4.34 \times 10^{04}$ & $1.05 \times 10^{03}$ & $1.99 \times 10^{04}$ & $5.91 \times 10^{02}$ \\
\hline Group 6 & 5 & average & high & $5.40 \times 10^{04}$ & $8.77 \times 10^{03}$ & $7.24 \times 10^{05}$ & $4.90 \times 10^{03}$ \\
\hline Group 7 & 3 & high & high & $9.75 \times 10^{04}$ & $7.49 \times 10^{04}$ & $9.20 \times 10^{05}$ & $4.08 \times 10^{05}$ \\
\hline Group 8 & 2 & high & low & $1.00 \times 10^{05}$ & $8.29 \times 10^{04}$ & $6.30 \times 10^{04}$ & $1.74 \times 10^{04}$ \\
\hline
\end{tabular}

Among the grouped stretches, Group 7 stands out as the group that needs the most care in relation to the landslide development. In group 7, stretches $362+600,093+$ xxxE and $419+000$ present high values of scar area and volume with high ranges of slope height and inclination, which can be interpreted as areas with predisposition for landslide occurrence. In cases of intervention measures, these would be the stretches that should be given priority.

Other stretches that need attention are in Group 3. Group 3 has seven slopes with high values for slope height and inclination, as well as ranges of values for the scar's area and volume. The stretches in Group 6 present average values for slope height with high slope inclinations, and when compared with the groups, stands out presenting high values for the scar area and volume variables.

The geographical aspect was analyzed, and allowed to sectorize the stretches in EFVM by cluster analysis. The groups formed are identified by characteristics of stretches in the group. Table 5 presents the stretches of EFVM with the results of cluster analysis. 


\begin{tabular}{c|c|c|c|c|c|c|c} 
Stretches & Group & Stretches & Group & Stretches & Group & Stretches & Group \\
\hline $011+000 \mathrm{D}$ & 1 & $094+330 \mathrm{D}$ & 8 & $458+600$ & 3 & $524+108$ & 4 \\
\hline $011+000 \mathrm{E}$ & 2 & $094+330 \mathrm{E}$ & 1 & $465+042 \mathrm{~A}$ & 4 & $535+419$ & 4 \\
\hline $018+500$ & 3 & $100+800$ & 4 & $465+042 \mathrm{~B}$ & 4 & $535+420$ & 4 \\
\hline $019+500$ & 2 & $103+100 \mathrm{D}$ & 2 & $472+228$ & 3 & $535+421$ & 4 \\
\hline $021+700$ & 2 & $103+100 \mathrm{E}$ & 1 & $472+307$ & 2 & $093+x x \times \mathrm{D}$ & 6 \\
\hline $034+000$ & 4 & $104+100 \mathrm{D}$ & 1 & $477+225$ & 3 & $093+x x \times \mathrm{E}$ & 7 \\
\hline $056+500$ & 4 & $104+100 \mathrm{E}$ & 2 & $478+500$ & 4 & $419+000$ & 7 \\
\hline $056+x x \mathrm{x}$ & 4 & $108+150$ & 2 & $482+299$ & 4 & $442+400$ & 8 \\
\hline $062+x \times \mathrm{D}$ & 5 & $359+675 \mathrm{~A}$ & 6 & $482+930$ & 4 & $521+000 \mathrm{E}$ & 4 \\
\hline $062+x x \mathrm{E}$ & 4 & $359+675 \mathrm{~B}$ & 2 & $493+600$ & 3 & $521+522$ & 3 \\
\hline $063+800 \mathrm{D}$ & 6 & $359+675 \mathrm{C}$ & 2 & $511+077$ & 4 & $079+410 \mathrm{D}$ & 4 \\
\hline $063+800 \mathrm{E}$ & 4 & $361+900$ & 2 & $511+670$ & 4 & $079+410 \mathrm{E}$ & 6 \\
\hline $064+x x \mathrm{x}$ & 4 & $362+600$ & 7 & $511+899$ & 4 & $404+000$ & 2 \\
\hline $072+500$ & 6 & $369+200 \mathrm{D}$ & 4 & $513+200$ & 3 & $409+000$ & 5 \\
\hline $073+500$ & 5 & $369+200 \mathrm{E}$ & 2 & $515+300$ & 4 & $519+900$ & 4 \\
\hline $078+900$ & 5 & $395+850$ & 2 & $518+790$ & 4 & $521+000 \mathrm{D}$ & 2 \\
\hline
\end{tabular}

Table 5

Sectorization of stretches in EFVM.

\section{Conclusions}

The application of cluster analysis allowed the identification of eight groups with intrinsic characteristics. In the classified groups, there can be identified stretches of group 7 , such as

\section{Acknowledgements}

The authors are grateful to Universidade Federal de Ouro Preto (UFOP), Fundação de Desenvolvimento da Pes-

\section{References}

$362+600,093+x x x E$ and $419+000$ with a tendency for landslides, due to the high values for slope height and inclination, along with considerable dimensions of scar area and volume.
Other groups can be cited, groups 3 and 6, with slope height and inclination values and considerable scar area and volume values. quisa de Minas Gerais (FAPEMIG) and the Coordenação de Aperfeiçoamento de Pessoal de Nível Superior (CAPES) for financial support and to Núcleo de Geotecnia da Escola de Minas of the Universidade Federal de Ouro Preto.

GOMES, R. C. Setorização Geológico-Geotécnica da Via e Avaliação e Controle de Riscos Geotécnicos dos Taludes da EFVM: Relatório Técnico Final. Ouro Preto: Universidade Federal de Ouro Preto, 2014.

GOOGLE EARTH PRO, versão 7.1.5.1557. Disponível em: <https://www.google. com.br/earth/download/gep/agree.html>. Acesso em: 23 nov. 2016.

GOWER J. C. A general coefficient of similarity and some of its properties. Biometrics, v. 27, p. 857-874, 1971.

GUTHRIE, R.H., EVANS, S.G. Analysis of landslide frequencies and characteristics in a natural system, coastal British Columbia. Earth Surface Processes and Landforms, v. 29, p. 1321-1339, 2004.

GUZZETTI, F., ARDIZZONE, F., CARDINALI, M., GALLI, M., REICHENBACH, P., ROSSI, M. Distribution of landslides in the Upper Tiber River basin, central Italy. Geomorphology, v. 96, p. 105-122, 2008.

GUZZETTI, F., ARDIZZONE, F., CARDINALI, M., ROSSI, M., VALIGI, D. Landslide volumes and landslide mobilization rates in Umbria, central Italy. Earth and Planetary Science Letters, v. 279, p. 222-229, 2009.

IMAIZUMI, F., SIDLE, R.C. Linkage of sediment supply and transport processes in Miyagawa Dam catchment, Japan. Journal Geophysical Research, v. 112, (F03012), 2007.

IMAIZUMI, F., SIDLE, R.C., KAMEI, R. Effects of forest harvesting on the occurrence of landslides and debris flows in steep terrain of central Japan. Earth Surface Processes and Landforms, v. 33, p. 827-840, 2008.

INNES, J.N. Magnitude-frequency relationships of debris flows in northwest Europe. 
Geographiska Annaler, v. 67A (1-2), p. 23-32, 1985.

KORUP, O. Distribution of landslides in southwest New Zealand. Landslides, v. 2, p. 43-51, 2005.

POLANCO, L. S. E. Correlações Empíricas para Fluxo de Detritos. Rio de Janeiro, RJ: COPPE/UFRJ, 2010. Originalmente apresentada como dissertação de mestrado, Universidade Federal do Rio de Janeiro, 2010.

R CORE TEAM. R: A language and environment for statistical computing

Foundation for Statistical Computing, Vienna, Austria. Disponível em: <https:// www.R-project.org>. Acesso em: 01 dez. 2016.

RICE, R.M., CORBETT, E.S., BAILEY, R.G. Soil slips related to vegetation, topography, and soil in Southern California. Water Resources Research, v. 5, n.3, p. 647-659, 1969.

SIMONETT, D.S. Landslide distribution and earthquakes in the Bewani and Torricelli Mountains, New Guinea. In: Jennings, J.N., Mabbutt, J.A. (Eds.), Landform Studies from Australia and New Guinea. Cambridge University Press, Cambridge, p. 64-84. 1967.

VALE. Sobre a Vale. Notícias. Disponível em: <http:/www.vale.com/brasil/PT/aboutvale/news/Paginas/ferrovia-vitoria-minas-transportou-119-milhoes-toneladas-cerca-1-milhao-pessoas-2014.aspx>. Acesso em: 27 de jan. 2017.

WARD, J. H., JR. "Hierarchical Grouping to Optimize an Objective Function", Journal of the American Statistical Association, v. 58, p. 236-244, 1963.

Received: 5 December 2017 - Accepted: 19 February 2018. 